\title{
Lithological analysis of 45 presumed pingo remnants in the northern Netherlands (Friesland): substrate control and fill sequences
}

\author{
S.J. Kluiving ${ }^{1,2,{ }^{*}}$, A.L.L.M. Verbers ${ }^{3}$ \& W.J.F. Thijs ${ }^{4}$ \\ 1 Institute for Geo- and Bioarchaeology, VU University Amsterdam, the Netherlands. \\ 2 GEO-LOGICAL, Earth Scientific Research \& Consultancy, Delft, the Netherlands. \\ 3 Landschapsbeheer Groningen, Groningen, the Netherlands. \\ 4 Archaeological Research \& Consultancy, Groningen, the Netherlands. \\ * Corresponding author. Email: sjoerd.kluiving@falw.vu.nl.
}

Manuscript received: March 2010, accepted: June 2010

\begin{abstract}
A number of 45 presumed pingo remnants have been analysed on lithological criteria while measured parameters of pingo remnants can be compared on a spatial scale. Methods used were hand augering and radiocarbon dating. Out of 45 cored sites thirty sites proved to represent pingo remnants after having tested the results according to the set of descriptive criteria. Does a difference in filling types in a spatial analysis influence the choice of early settlers in this region? Results show that two groups of pingo remnants can be distinguished by the nature of the pingo filling. Type 1 pingo remnants with predominantly peat filling are found in the lower valleys between the higher glacial till ridges. Type 2 pingo remnants with equal loam and peat filling are predominantly found on the higher glacial till ridges. Type 2 pingo remnants generally have a greater depth, are more ellipsoid in shape, and have a steeper slope angle than type 1 pingo remnants on the lower terrain. Results indicate that the substrate character influenced the development of infilling of pingo remnants. Marshy environments may have existed for a prolonged period throughout the Holocene in pingo remnants on the glacial ridges, while pingo remnants on the lower terrain are filled in by peat bogs. Landscape evolution based on the results of a distinct dataset of pingo remnants can help to solve archaeological problems of settlement issues when combined with new palaeobotanic data and high resolution dates.
\end{abstract}

Keywords: Pingo remnants, Friesland, landscape evolution, substrate, fill sequences

\section{Introduction}

Pingos, or ice frost hills, are still one of the most spectacular phenomena occuring in periglacial climates in the northern latitudes, such as present Siberia in Russia or in the North-West Territories in Canada. Pingos are intra-permafrost ice-cored hills, typically conical in shape that can grow and persist only in a permafrost environment (Mackay, 1998). Pingo remnants occur both in active periglacial as well as in former periglacial environments. Although in the Netherlands periglacial phenomena from the Weichselian period such as pingo remnants have also been recognised in the more southern regions of the Netherlands and even in Belgium (e.g. Kasse \& Bohncke, 1992), pingo remnants have been reported mainly from the northern half of the Netherlands (Maarleveld \& Van den Toorn, 1955; De Gans, 1982; Bijlsma \& De Lange, 1983; De Groot et al., 1987; De Gans, 1988; Van der Meulen, 1988; Hoek, 2005).

The filling of the pingo remnant with loam, peat, and gyttja takes place from the start of collapse (10-13 k years BP) to the present (De Gans, 1982, 1988; De Groot et al. 1987; Kasse \& Bohncke, 1992; Hoek, 2005).

The majority of pingos in the Netherlands were formed during the Upper Pleniglacial, when discontinuous permafrost conditions prevailed. Continuous growth of the pingo ice-core lead to mass wasting, permafrost creep, and eventually rupture of the pingo skin (De Gans, 1982). The degradation of these pingos began during the temperature rise at the onset of the Bølling warm interval and was completed during this period. As 
a result hundreds of small, isolated lake basins were formed in the northern Netherlands at this time. Therefore, most of the remnants contain a suite of Lateglacial and Holocene sediments (Davies at al., 2005; Bohncke 1993; Hoek \& Bohncke 2002). In the past the setting and spatial pattern of pingo remnants in the northern Netherlands have been attributed to former alluvial and periglacial valleys (e.g. De Gans, 1988; Nossin, 1961; Van der Meulen, 1988).

The subject of this paper is dealing with a dataset of 45 presumed pingo remnants from a former periglacial environment in the Northern Netherlands (Fig. 1). Potentially the fill sequences of pingo remnants form an ideal palaeobotanic record of the Holocene and Late-Weichselian periods. Only very few palaleobotanic data have a record that span from the Late Glacial throughout the Holocene (e.g. Van Geel et al., 1981). Most palaeobotanic work is concentrated on the Late Weichselian / Holocene transition (Bijlsma \& De Lange, 1983; Bos \& Jansen, 1996; Hoek, 2005) while there were few publications about Holocene paleobotanic data that can help to interpret landscape changes in Mid-Holocene periods when the first humans entered the Friesland/Groningen area in the Neolithic (Bakker, 2003). Pingos have always been regarded as potentially valuable habitation sites for hunter-gatherers. Most pingo-remnants have been filled with organic sediments since then. Currently, these sediments are being dug out in order to create ponds to change the faunal make-up of the area. Because too little is known about the archaeological value of these features, potential sources of information are currently being destroyed (Van Geel et al., 1981; De Gans, 2000; pers. comm. G. de Lange, 2009, Province of Friesland, the Netherlands).

In the entire province of Friesland 850 locations of presumed pingo remnants or circular waters are present (Kluiving \& Verbers, 2007). At the moment it is unclear whether these circular landforms represent Weichselian pingo remnants, Holocene dobben, eolian depressions or other types of landforms. Dobben are excavated pools for drinking- or fire extinguishing water, commonly used as watering place for cattle.

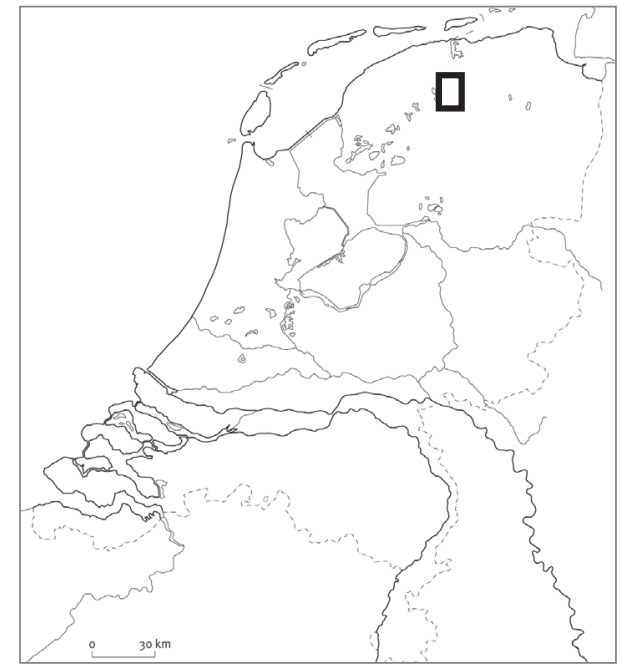

Fig. 1. a. Position of study area in the Netherlands; b. Study area in the eastern part of the province of Friesland with indicated circular terrain forms, which may be either pingo remnants or pools (dobben). Legend for pingo remnant classification: 1 - (light green): no value; 2 - (red): pingo remnant - high value; 3 - (darkgreen): pingo remnant - dredged, 'cleaned'; 4 - (purple): presumed pingo remnant value unknown; 5 - (blue): presumed pingo remnant - this study (incl. number) (source map: Province of Friesland, 2006).

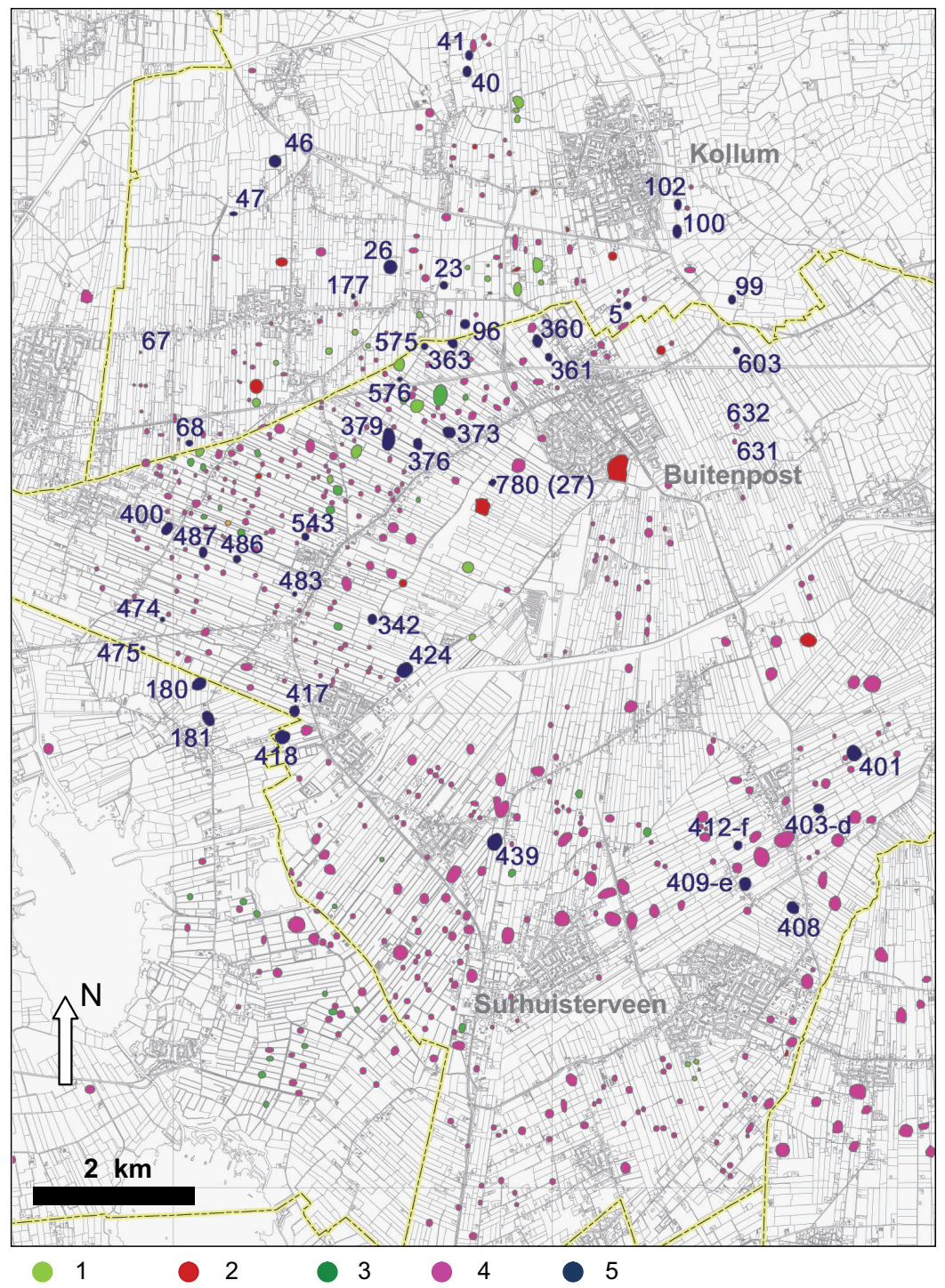


The primary goal of this research was to classify and value presumed pingo remnants in a specific part of the province of Friesland (Fig. 1). In the municipalities of Dantumadeel, Kollumerland, Tytsjerksteradeel and Achtkarspelen a cluster of more than 250 circular landforms, usually filled with water, is present on and around a Pleistocene till plateau (Fig. 2). After the valuation of the presumed pingo remnants, the objective of this research project was to propose valuable pingo remnants for the provincial archaeological monument map.

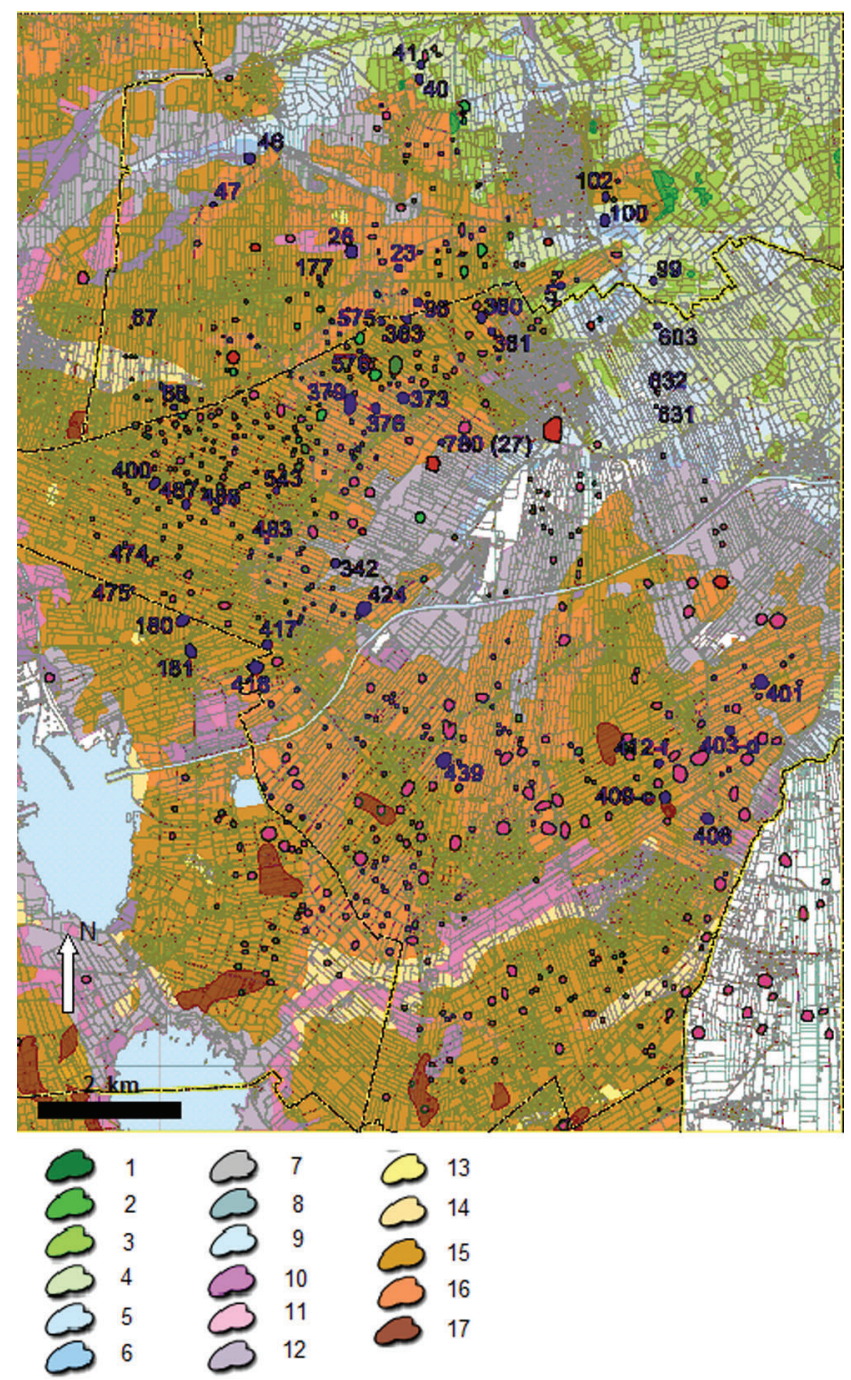

Fig. 2. Geological map of the study area with numbered locations of presumed pingo remnants of this study. For legend of circular terrain forms see caption of Fig. 1. Legend: Clay (Holocene) (with surface elevation according to NAP (National Ordnance Datum)): 1 ->1.5 m NAP; 2 - 1-1.5 m NAP; 3-0,50-1,00 m NAP; 4-0-0.5 m NAP; 5-0.5-0 m NAP; 6 - 1-0.5 m NAP. Cultural elements: 7 - Buildings; 8 - Reclaimed land; 9 - Inland waterway. Peat landscape (Holocene): 10 - Clay on peat (claycover $>0.4 \mathrm{~m}$ thick); 11 - Peat; 12 - Residual peat. Saalian and Weichselian deposits (Pleistocene): 13 - Subglacial till at the surface (Saalian); 14 - No subglacial till (Saalian) present in the subsurface, or till deeper than $2 \mathrm{mbs} ; 15$ Fluvioglacial deposits (Weichselian) within $2 \mathrm{~m}$ bs; 16 - Subglacial till (Saalian) within $2 \mathrm{~m}$ bs; 17 - Saalian deposits, but no subglacial till, within $2 \mathrm{~m}$ bs. bs = below surface (source map: Province of Friesland, 2010).
Generally speaking, there is little evidence for the presence of Meso- or Neolithic hunters (Bakker, 2003) but the fact that their cultural remains cannot be found in pingo remnants is questionable (pers. comm I. Woltinge, 2009, Groningen Institute of Archaeology, the Netherlands). Therefore the question is raised if landscape evolution can be reconstructed on the basis of a distinct dataset of pingo remnants and if such a reconstruction can help to solve archaeological problems of settlement issues. What relation exists between different types of organic filing within pingo remnants in addition to valuable palaeobotanic data for Holocene landscape reconstruction? Is there a spatial pattern in the morphometric parameters of pingo remnants, and if so, what is causing this pattern?

\section{Selecting criteria}

In the process of selecting sites from the 250 circular landforms prior to field investigation the emphasis was partly to select as many presumed pingo remnants based on former published and unpublished research. A spatial criterion was also used to select sites with a circular interspacing of at least $1 \mathrm{~km}$ in order to set up a random sample survey for palaeobotanic research. These two criteria were applied which resulted in a selection of 45 landforms to investigate in the field by coring methods (Fig. 1).

Geological criteria of pingo remnant identification were formulated prior to the fieldwork, including three dimensional shape, stratigraphy and lithology of filling, as well as surface morphology. To judge whether presumed pingo remnants represent true pingo remnants, a basic set of criteria from Canada is used of Mackay (1998), added with criteria for the Netherlands of De Gans (1982, 1988; Table 1).

Table 1. Diagnostic criteria for identification of pingo remnants. Data from De Gans (1982) and Mackay (1998).

\begin{tabular}{|c|c|}
\hline Publication & Criterion \\
\hline \multirow[t]{4}{*}{ Mackay, 1998} & - Sides of the erosional form represent steep slopes \\
\hline & - Depressions are filled with peat \\
\hline & - Surrounding the depression a rampart is present \\
\hline & $\begin{array}{l}\text { - Pingo remnants are more or less circular in outline, } \\
\text { or have a fairly uniform diameter }\end{array}$ \\
\hline De Gans, 1982, & - Weichselian age \\
\hline \multirow[t]{5}{*}{1988} & $\begin{array}{l}\text { - Minimal depth of central depression is } 1.5 \text { meter } \\
\text { with a minimum diameter of } 25 \text { meter }\end{array}$ \\
\hline & $\begin{array}{l}\text { - Bottom of the central depression lies below } \\
\text { surrounding topography and is floored by material } \\
\text { sufficiently permeable to allow migration of } \\
\text { groundwater }\end{array}$ \\
\hline & - At least part of a rampart is present \\
\hline & $\begin{array}{l}\text { - Pingo remnants occur on flat ground or on slopes } \\
\text { with a gradient up to } 5^{\circ}\end{array}$ \\
\hline & $\begin{array}{l}\text { - Pingo remnants are accompanied by other } \\
\text { permafrost phenomena }\end{array}$ \\
\hline
\end{tabular}


It has already been noted that studies on their infill material can be expected to supply a wealth of data for stratigraphical and environmental studies on the period since the late Glacial (De Gans, 1988).

\section{Methods and materials}

In the summer of 2006 and the winter of 2006/2007 in an area of 9000 ha a total number of 582 cores were carried out at the 45 sites that were presumed to be pingo remnants (Fig. 2). Standard Edelman $7 \mathrm{~cm}$ auger and $3 \mathrm{~cm}$ gouge were used to retrieve sediments. Sediment logs were made using standard description conform the Dutch protocol NEN5104 (Bosch, 2000). Radiocarbon dating on the organic filling of four sites was performed by the Groningen University (RUG). A total of 10 radiocarbon dates have been obtained from peat, clay and gyttja samples, measuring bulk organic matter. No reservoir corrections have been applied and the dates are presented as uncalibrated. Besides the sediment descriptions in the field no additional laboratory analysis has been performed in this study. A digital catalogue has been published in which descriptions of the 45 locations are presented (Kluiving \& Verbers, 2007). The catalogue has put an emphasis on the (form of) eroded substrate, the organic filling, as well as the cover layers next to additional earth scientific and administrative data. For each investigated site the following data are available: a) a field map with borehole locations and a peat contour (contouring cores with a pingo filling with peat; b) bore hole log data; c) a cross section showing the lithostratigraphic associations of units of subsurface, pingo filling, and cover layer, d) photos. The project was concluded with an evaluation of the research project (Kluiving \& Verbers, 2007). In this paper the results of the catalogue have been further analysed to answer the proposed research questions.

\section{Results}

Out of 45 cored sites thirty sites proved to represent pingo remnants after having tested the results according to the set of descriptive criteria as listed in Table 1. Fifteen presumed pingo remnants can be classified as other landforms, such as excavated small basins filled with organic material and partly with standing water (Dutch: dobben) and eolian depressions filled with peat.

The combined characteristics of all 45 sites are summarised in Table 2. Results from the coring fieldwork presented peat contours outlining the plan-shape of the organic filling, when peat is present in the presumed pingo remnant. The longest and shortest axes of the plan shape of the organic filling of each presumed pingo remnant are listed in Table 2. In the table the criterion of peat shape eccentricity is obtained, using the formula for an ellipse $\left(x^{2} / a^{2}\right)+\left(y^{2} / b^{2}\right)=1$. Peat shape eccentricity is determined in this study in order to test and add to potential descriptive criteria of pingo remnants (cf. Mackay, 1998). Eccentricity is defined as the square root of $\left(1-b^{2} / a^{2}\right)$, with 0 representing a perfect circle, and 1 representing a perfect ellipse. The values in the dataset range from 0 to 0.9 . When no peat contour is present there will also be no value for peat shape eccentricity.

Based on the coring results the maximum thickness values of the organic filling are listed as the maximum thickness of the 'peat' layer as well as that of the 'loam' layer. Based on the thickness of the sum of humic loam and organic filling and the shortest axis of the plan shape of the organic filling the slope angle of the deformed shape is calculated. Slope angle values range from less than $3^{\circ}$ to more than $14^{\circ}$. The presence of a thin fine sandy layer is indicated when present below the pingo filling, at the interface of the substrate and the pingo filling. The sandy layer can range in thickness less than $1 \mathrm{~cm}$ to a maximum of $10 \mathrm{~cm}$. In a number of cases corings were not deep enough to establish the lower boundary of the sand layer. In those cases the presence of the sand layer is marked with a c. When the cores did not go deep enough to reach the base of the filling the presence of the sand layer is noted as n.o. (no observation). Based on the combined characteristics of the 45 presumed pingo remnants (cf. Kluiving \& Verbers, 2007), a general analysis of results on descriptive criteria is presented in five classes as I: Pingo remnant, best quality $(n=7)$, II Pingo remnant, general $(n=19)$, II: Pingo remnant, disturbed $(n=4)$, III: Pingo remnant, possible $(n=5)$, IV: Other landform $(n=10)$ (Table 2).

The results presented will focus hereafter on the 30 established pingo remnants from this study (Table 2), and analyse the sedimentological descriptive data from this set of pingo remnants. Although it may doubtful if the smallest, shallowest depression may, due to its small size, classify as a pingo remnant, its specification is conform the selected criteria of steep sides, and lithology of filling in Table 1.

The clearest examples with respect to the physical quality of the organic filling unit show asymmetric troughs with steep sides with a characteristic filling, and significant thickness of loam and peat sequences (class I, Table 2). In general no ramparts have been observed within the dataset, only in a few cases possible erosion rests of buried ramparts have been interpreted from core descriptions.

\section{Lithology of 30 pingo remnants}

The pingo remnants vary strongly in depth. The deepest pingo remnant was 8 meters below surface; the shallowest were 2 to 2.5 meter below the surface (Table 2). The lithostratigraphic units of the pingo remnants will be discussed describing first the subsurface units, second the pingo filling which usually consists of two subunits, and third the nature of the cover layer. 


\begin{tabular}{|c|c|c|c|c|c|c|c|c|c|c|c|}
\hline 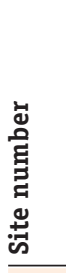 & 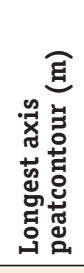 & 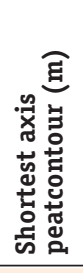 & 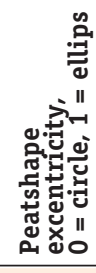 & 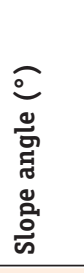 & 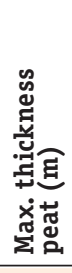 & 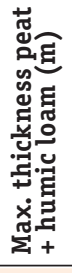 & 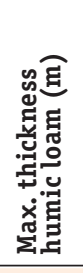 & 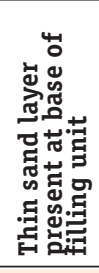 & 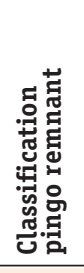 & 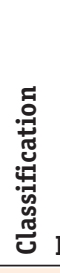 & Interpretation, $\mathrm{pr}=$ pingo remnant \\
\hline 5 & 80 & 70 & 0.48 & 3.11 & 1.6 & 1.9 & 0.3 & $\mathrm{y}$ & $\mathrm{y}$ & I & pr, characteristic filling \\
\hline 26 & 110 & 70 & 0.77 & 5.87 & 1.7 & 3.6 & 1.9 & $\mathrm{y}$ & $\mathrm{y}$ & I & fine pr, relatively deep filling, possible rampart \\
\hline 181 & 120 & 120 & 0 & 7.22 & 2.6 & 7.6 & 5 & $\mathrm{y}$ & $\mathrm{y}$ & Is & splendid pr, deepest within dataset \\
\hline 342 & 80 & 60 & 0.66 & 4.95 & 2.3 & 2.6 & 0.3 & $\mathrm{y}$ & $\mathrm{y}$ & I & whole, intact pr, rampart unclear \\
\hline 439 & 110 & 70 & 0.77 & 6.84 & 3.5 & 4.2 & 0.7 & $\mathrm{y}$ & $\mathrm{y}$ & I & fine pr, thick peat sequence \\
\hline 486 & 50 & 40 & 0.6 & 8.53 & 1.8 & 3 & 1.2 & c & $\mathrm{y}$ & Is & splendid pr, locally intact to the top \\
\hline 603 & 110 & 100 & 0.42 & 5.71 & 4 & 5 & 1 & $\mathrm{y}$ & $\mathrm{y}$ & I & most splendid and whole pr of entire dataset \\
\hline 23 & 100 & 60 & 0.80 & 5.14 & 2 & 2.7 & 0.7 & c & $\mathrm{y}$ & II $s$ & small pr, characteristic filling, possible rampart, sand substrate \\
\hline 46 & 20 & 20 & 0 & 2.86 & 0.5 & 0.5 & 0 & $\mathrm{y}$ & $\mathrm{y}$ & II $s$ & small pr \\
\hline 47 & 45 & 10 & 0.97 & 14.57 & 0.8 & 1.3 & 0.5 & $\mathrm{y}$ & $\mathrm{y}$ & II & relatively extensive, shallow pr \\
\hline 68 & 120 & 40 & 0.94 & 7.13 & 1.3 & 2.5 & 1.2 & $\mathrm{y}$ & $\mathrm{y}$ & II & fine, well preserved pr \\
\hline 99 & 80 & 60 & 0.66 & 4.95 & 2.5 & 2.6 & 0.1 & $\mathrm{y}$ & $\mathrm{y}$ & II & fine, well preserved pr \\
\hline 100 & 160 & 60 & 0.93 & 5.33 & 2.6 & 2.8 & 0.2 & $\mathrm{y}$ & $\mathrm{y}$ & II $s$ & small, well preserved pr steep sides, possible rampart \\
\hline 102 & 130 & 60 & 0.89 & 3.62 & 1.8 & 1.9 & 0.1 & c & $\mathrm{y}$ & II & whole, intact pr, characteristic extended north-south plan shape \\
\hline 180 & 130 & 90 & 0.72 & 4.45 & 1.6 & 3.5 & 1.9 & n.o. & $\mathrm{y}$ & II & relatively intact pr, peat on top of humic loam \\
\hline 373 & 70 & 40 & 0.82 & 8.53 & 2 & 3 & 1 & $\mathrm{y}$ & $\mathrm{y}$ & II & pr, relatively deep erosion, characteristic filling \\
\hline 376 & 70 & 60 & 0.52 & 3.24 & 1.3 & 1.7 & 0.4 & c & $\mathrm{y}$ & II & pr, characteristic filling on subglacial till, possible rampart, sand substrate \\
\hline 379 & 170 & 70 & 0.91 & 4.57 & 1 & 2.8 & 1.8 & y & $\mathrm{y}$ & II & large and deep pr, characteristic filling on top of very fine sand \\
\hline 400 & 70 & 50 & 0.7 & 7.29 & 1.4 & 3.2 & 1.8 & $\mathrm{y}$ & $\mathrm{y}$ & II & pr, filling of peat of variable thickness, double sand layers at top substrate \\
\hline 401 & 150 & 100 & 0.75 & 2.75 & 1.2 & 2.4 & 1.2 & $\mathrm{y}$ & $\mathrm{y}$ & II & pr, central part dredged, steep sides \\
\hline 408 & 90 & 80 & 0.46 & 3.58 & 2.5 & 2.5 & 0 & $\mathrm{y}$ & $\mathrm{y}$ & II & possible pr, absence of humic loam sequence \\
\hline 409 & 50 & 40 & 0.60 & 4.86 & 0.9 & 1.7 & 0.8 & $\mathrm{y}$ & $\mathrm{y}$ & II $s$ & small pr in eolian depression, on top of abraded till with cover sand \\
\hline 412 & 60 & 50 & 0.55 & 5.71 & 2.5 & 2.5 & 0 & $\mathrm{y}$ & $\mathrm{y}$ & II & pr, pottery clay and 'Peelo sands' as substrate, possible rampart \\
\hline 418 & 100 & 100 & 0 & 2.98 & 1.8 & 2.6 & 0.8 & $\mathrm{y}$ & $\mathrm{y}$ & II & fine pr, humic loam superponed by multiple peat types \\
\hline 424 & 140 & 100 & 0.7 & 2.63 & 0.7 & 2.3 & 1.6 & $\mathrm{y}$ & $\mathrm{y}$ & II & pr on top of abraded till, peat on relatively thick humic loam \\
\hline 543 & 60 & 50 & 0.55 & 4.35 & 1.5 & 1.9 & 0.4 & n.o. & $\mathrm{y}$ & II $s$ & small well preserved pr \\
\hline 27 & 80 & 80 & 0 & 2.15 & 1.5 & 1.5 & 0 & n.o. & $\mathrm{y}$ & III & original intact pr, disturbed \\
\hline 96 & 60 & 40 & 0.75 & 7.41 & 0.7 & 2.6 & 1.9 & c & $\mathrm{y}$ & III & original small pr disturbed by dredging \\
\hline 403 & 110 & 90 & 0.57 & 3.81 & 2.7 & 3 & 0.3 & $\mathrm{y}$ & $\mathrm{y}$ & III & pr surrounded by relief of cover sand, central part of filling dredged \\
\hline 576 & 30 & 25 & 0.55 & 7.29 & 0.8 & 1.6 & 0.8 & $\mathrm{y}$ & $\mathrm{y}$ & III s & small pr partly reclaimed for peat, anthropgenically filled up afterwards \\
\hline 40 & 90 & 50 & 0.83 & - & 0.4 & 6.2 & 5.8 & $\mathrm{y}$ & $\mathrm{y} / \mathrm{n}$ & IV & possible pr, afterwards transformed to pothole by (kolk) erosion \\
\hline 41 & 70 & 60 & 0.52 & - & 0.7 & 5.8 & 5.1 & $\mathrm{y}$ & $\mathrm{y} / \mathrm{n}$ & IV & possible pr, afterwards transformed to pothole by (kolk) erosion \\
\hline 360 & 80 & 40 & 0.87 & - & 0.7 & 0.7 & 0 & $\mathrm{n}$ & $\mathrm{y} / \mathrm{n}$ & IV & possible pr, flooded \\
\hline 361 & 70 & 50 & 0.7 & - & 1.5 & 3.5 & 2 & $\mathrm{n}$ & $\mathrm{y} / \mathrm{n}$ & IV & possible pr, well preserved peat stratigraphy \\
\hline 575 & 50 & 50 & 0 & - & 0.9 & 1.5 & 0.6 & $\mathrm{n}$ & $\mathrm{y} / \mathrm{n}$ & IV & possible pr in cover sand on top of subglacial till. \\
\hline 0 & 0 & 0 & - & - & 0.5 & 0.5 & 0 & $\mathrm{n}$ & $\mathrm{n}$ & $\mathrm{V} s$ & shallow depression in subglacial till \\
\hline 67 & 0 & 0 & - & - & 0 & 0 & 0 & n.o. & $\mathrm{n}$ & $\mathrm{V}$ & excavated depression (dobbe) afterwards filled-up \\
\hline 363 & 70 & 40 & 0.82 & - & 0.7 & 1.6 & 0.9 & $\mathrm{n}$ & $\mathrm{n}$ & $\mathrm{V}$ & possible depression in subglacial till \\
\hline 417 & 0 & 0 & - & - & 0 & 0 & 0 & n.o. & $\mathrm{n}$ & $\mathrm{V}$ & excavated depression \\
\hline 474 & 0 & 0 & - & - & 0 & 0.9 & 0.9 & n.o. & $\mathrm{n}$ & $\mathrm{V}$ & excavated depression \\
\hline 475 & 0 & 0 & - & - & 0 & 0.8 & 0.8 & $\mathrm{n}$ & $\mathrm{n}$ & $\mathrm{V}$ & excavated depression in subglacial till \\
\hline 483 & 0 & 0 & - & - & 0 & 0.0 & 0 & n.o. & $\mathrm{n}$ & $\mathrm{V}$ & depression originating from eroding subglacial till \\
\hline 487 & 0 & 0 & - & - & 0 & 0.0 & 0 & n.o. & $\mathrm{n}$ & $\mathrm{V}$ & depression in subglacial till \\
\hline 631 & 90 & 70 & 0.63 & - & 2 & 2 & 0 & $\mathrm{n}$ & $\mathrm{n}$ & $\mathrm{V}$ & depression in coversand filled with Holocene peat \\
\hline 632 & 0 & 0 & - & - & 2.1 & 2.1 & 0 & $\mathrm{n}$ & $n$ & $\mathrm{~V}$ & depression with peat in coversand on top of abraded subglacial till \\
\hline
\end{tabular}

Classification - I Pingo remnant, best quality; II Pingo remnant, general; III Pingo remnant, disturbed; IV Pingo remnant, possible; V Other landform Legend thin sand layer - y present; $c$ base sand not reached; n.o. base filling not reached. 


\section{Substrate}

All pingo remnants show a depression in the subsurface that is predominantly shaped in an ellipsoid form, inferred on the eccentricity of the plan shape of the peat contour (Table 2). Asymmetric shapes of the depressions show occasionally in cross section with a steeper northern slope. In the subsurface the substrate material within the research area is variable and consists in general of three units, which are interpreted as the deposits originating from three ice ages Elsterian, Saalian and Weichselian:

a. a grey to brown grey weak (sandy) loam to weak silty clay interpreted as Elsterian clay (Dutch: potklei; Peelo Formation). On top of the clay a very fine white micaceous sand is present which is also interpreted as the Peelo Formation;

b. a sandy loam with weak to medium gravel content interpreted as a Saalian till or an unsorted gravelly sand interpreted as the erosional product of a till (Dutch: keizand; Drenthe Formation);

c. occasionally, higher up in the sequence (but also deformed by the erosional form of the pingo remnant), a very fine to medium sized sand is found, interpreted as a Weichselian aeolian sand, also known as cover sand (Boxtel Formation, Wierden member). In those cases where the eolian sand of the Boxtel Formaton is cut by the erosional form, the time of pingo formation is younger than the deposition of the Wierden member.

A consistent factor of the established pingo remnants in the study area is the presence of a thin layer of light coloured, very fine slightly silty sand ( $\mu$ values $63-210$ ), with characteristic fine grained mica throughout, at the base of the organic filling (Table 2). This thin layer of sand occurs on top of the substrate materials described above; in most cases the thin sandy layer occurs on top of the pottery clay and in some cases on top of the till layer as well. The thin sand layer is interpreted to be of the Peelo Formation, given lithological and mineralogical similarities, and thus Elsterian in age, but it has most likely been reworked in the pingo formation process during the Late Glacial of the Weichselian. The original stratigraphic position of the fine sand was on top of the pottery clay and below the subglacial till of the Drenthe Formation (if present). In some cases corings could not be drilled to the lower boundary of the sand layer, in those cases the original stratigraphy of the Peelo sands may be intact (marked as c (conditional) in Table 2).

\section{Pingo filling unit}

According to the character of the pingo filling unit we distinguish two groups within the 30 interpreted pingo remnants: a group with two distinct layers within the filling unit and a group with a rather dominant peat unit. The distinction was clearly observed in the field and also shows when layer thicknesses of (maximum) humic loam and peat are compared (Fig. 3; Table 3). The criterion of distinction between the two groups is the $30 \%$ value of humic loam layers: when less than $30 \%$ of the total filling is made up of loam layers a type 1 organic filling is distinguished; when more than $30 \%$ of the total filling consists of humic loam a type 2 organic filling is distinguished. The value of $30 \%$ is rather arbitrary but based on the apparent hiatus in the plot (Fig. 4). The plot of the percentages is rather transitional than abrupt, but given the clear geographical spreading of the two types the division into two types appears to be significant (Fig. 3). Another distinguishing criterion is that the type 2 pingo remnants are slightly more elliptical (average eccentricity: 0.67) in plan-shape than type 1 pingo remnants (average eccentricity 0.52; Table 3). Also the average slope angle of the pingo erosional form is slightly higher in type 2 pingo remnants (slope angle $6.65^{\circ}$ ) than in type 1 pingo remnants (slope angle $4.25^{\circ}$; Table 3 ).

In addition the two types of filling appear strongly related in areal extent to the underlying geology and topography (Fig. 5). The type 2 organic filling, i.e. the loam-peat types, occur grouped in the northwest of the study area on the highest part of the till plateau. Type 1 organic filling, i.e. the peat types, occur also grouped, but are situated in the east on the lower regional part with younger deposits overlying the till or the till not present at all.

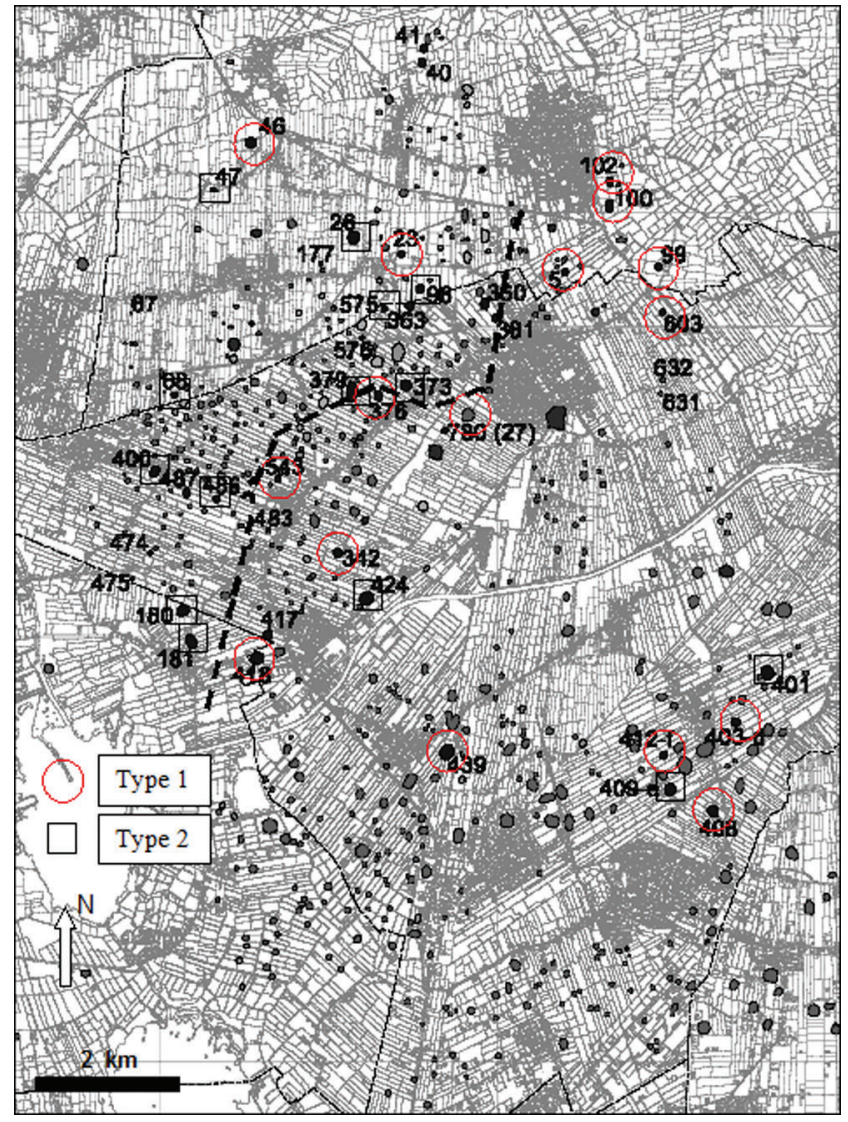

Fig. 3. Map of study area with pingo remnants of type 1 (circles) and of type 2 (rectangles). See text for further explanation (source map: Province of Friesland, 2006). 
Table 3. Summary of results of pingo remnant research $(n=30)$, ordered by type of pingo filling.

\begin{tabular}{|c|c|c|c|c|c|c|c|c|c|c|}
\hline $\begin{array}{l}\text { Site } \\
\text { number }\end{array}$ & $\begin{array}{l}\text { Longest } \\
\text { axis peat } \\
\text { contour } \\
\text { (m) }\end{array}$ & $\begin{array}{l}\text { Shortest } \\
\text { axis peat } \\
\text { contour } \\
(\mathrm{m})\end{array}$ & $\begin{array}{l}\begin{array}{l}\text { Peat-shape } \\
\text { excentricity, }\end{array} \\
0=\text { circle, } \\
1=\text { ellips }\end{array}$ & $\begin{array}{l}\text { Slope } \\
\text { angle } \\
\left({ }^{\circ}\right)\end{array}$ & $\begin{array}{l}\text { Max. } \\
\text { thickness } \\
\text { peat (m) }\end{array}$ & $\begin{array}{l}\text { Max. } \\
\text { thickness } \\
\text { peat + humic } \\
\text { loam }(\mathrm{m})\end{array}$ & $\begin{array}{l}\text { Max. } \\
\text { thickness } \\
\text { humic } \\
\operatorname{loam}(\mathrm{m})\end{array}$ & $\begin{array}{l}\text { \% Humic } \\
\text { loam in } \\
\text { total filling } \\
\text { unit } \\
\end{array}$ & $\begin{array}{l}\% \text { Peat in } \\
\text { total filling } \\
\text { unit }\end{array}$ & $\begin{array}{l}\text { Thin sand } \\
\text { layer present } \\
\text { at base of } \\
\text { filling unit }\end{array}$ \\
\hline Type & 1 & & & & & & & & & \\
\hline 376 & 70 & 60 & 0.52 & 3.24 & 1.3 & 1.7 & 0.4 & 24 & 76 & c \\
\hline 23 & 100 & 60 & 0.80 & 5.14 & 2.0 & 2.7 & 0.7 & 26 & 74 & c \\
\hline 46 & 20 & 20 & 0.00 & 2.86 & 0.5 & 0.5 & 0.0 & 0 & 100 & $\mathrm{y}$ \\
\hline 99 & 80 & 60 & 0.66 & 4.95 & 2.5 & 2.6 & 0.1 & 4 & 96 & $\mathrm{y}$ \\
\hline 408 & 90 & 80 & 0.46 & 3.58 & 2.5 & 2.5 & 0.0 & 0 & 100 & $\mathrm{y}$ \\
\hline 102 & 130 & 60 & 0.89 & 3.62 & 1.8 & 1.9 & 0.1 & 5 & 95 & $\mathrm{y}$ \\
\hline 27 & 80 & 80 & 0.00 & 2.15 & 1.5 & 1.5 & 0.0 & 0 & 100 & n.o. \\
\hline 412 & 60 & 50 & 0.55 & 5.71 & 2.5 & 2.5 & 0.0 & 0 & 100 & $\mathrm{y}$ \\
\hline 100 & 160 & 60 & 0.93 & 5.33 & 2.6 & 2.8 & 0.2 & 7 & 93 & $\mathrm{y}$ \\
\hline 5 & 80 & 70 & 0.48 & 3.11 & 1.6 & 1.9 & 0.3 & 16 & 84 & $\mathrm{y}$ \\
\hline 342 & 80 & 60 & 0.66 & 4.95 & 2.3 & 2.6 & 0.3 & 12 & 88 & $\mathrm{y}$ \\
\hline 439 & 110 & 70 & 0.77 & 6.84 & 3.5 & 4.2 & 0.7 & 17 & 83 & $\mathrm{y}$ \\
\hline 603 & 110 & 100 & 0.42 & 5.71 & 4.0 & 5.0 & 1.0 & 20 & 80 & $\mathrm{y}$ \\
\hline 418 & 100 & 100 & 0.00 & 2.98 & 1.8 & 2.6 & 0.8 & 31 & 69 & $\mathrm{y}$ \\
\hline 543 & 60 & 50 & 0.55 & 4.35 & 1.5 & 1.9 & 0.4 & 21 & 79 & n.o. \\
\hline 403 & 110 & 90 & 0.57 & 3.81 & 2.7 & 3.0 & 0.3 & 10 & 90 & $\mathrm{y}$ \\
\hline Average & 90 & 66.9 & 0.52 & 4.27 & 2.2 & 2.5 & 0.3 & 12 & 88 & \\
\hline
\end{tabular}

\begin{tabular}{|c|c|c|c|c|c|c|c|c|c|c|}
\hline Type & 2 & & & & & & & & & \\
\hline 373 & 70 & 40 & 0.82 & 8.53 & 2.0 & 3.0 & 1.0 & 33 & 67 & $\mathrm{y}$ \\
\hline 47 & 45 & 10 & 0.97 & 14.57 & 0.8 & 1.3 & 0.5 & 38 & 62 & $\mathrm{y}$ \\
\hline 486 & 50 & 40 & 0.60 & 8.53 & 1.8 & 3.0 & 1.2 & 40 & 60 & c \\
\hline 26 & 110 & 70 & 0.77 & 5.87 & 1.7 & 3.6 & 1.9 & 53 & 47 & $\mathrm{y}$ \\
\hline 181 & 120 & 120 & 0.00 & 7.22 & 2.6 & 7.6 & 5.0 & 66 & 34 & $\mathrm{y}$ \\
\hline 68 & 120 & 40 & 0.94 & 7.13 & 1.3 & 2.5 & 1.2 & 48 & 52 & $\mathrm{y}$ \\
\hline 180 & 130 & 90 & 0.72 & 4.45 & 1.6 & 3.5 & 1.9 & 54 & 46 & n.o. \\
\hline 379 & 170 & 70 & 0.91 & 4.57 & 1.0 & 2.8 & 1.8 & 64 & 36 & $\mathrm{y}$ \\
\hline 400 & 70 & 50 & 0.70 & 7.29 & 1.4 & 3.2 & 1.8 & 56 & 44 & $\mathrm{y}$ \\
\hline 401 & 150 & 100 & 0.75 & 2.75 & 1.2 & 2.4 & 1.2 & 50 & 50 & $\mathrm{y}$ \\
\hline 409 & 50 & 40 & 0.60 & 4.86 & 0.9 & 1.7 & 0.8 & 47 & 53 & $\mathrm{y}$ \\
\hline 424 & 140 & 100 & 0.70 & 2.63 & 0.7 & 2.3 & 1.6 & 70 & 30 & $\mathrm{y}$ \\
\hline 96 & 60 & 40 & 0.75 & 7.41 & 0.7 & 2.6 & 1.9 & 73 & 27 & c \\
\hline 576 & 30 & 25 & 0.55 & 7.29 & 0.8 & 1.6 & 0.8 & 50 & 50 & $\mathrm{y}$ \\
\hline Average & 105 & 68 & 0.67 & 6.65 & 1.3 & 3.1 & 1.8 & 57 & 43 & \\
\hline
\end{tabular}

Legend thin sand layer - y present; c base sand not reached; n.o. base filling not reached.

Type 1 ( $n=14)$ : The filling of the erosion form consists almost entirely of peat, with usually Sphagnum peat at the base (nrs 5 , $23,27,46,99,100,102,342,376,403,408,412,418,439,543$, and 603). On average the peat sequence is more than 7 times as thick as a humic loam layer (averages: 2.2 meter versus 0.3 meter; Table 3).

a. The basal filling layer of type 1 fillings ranges from 0 up to a maximum of 1 meter. The relatively thin layer generally starts with a yellow-brown colored loam containing humus and root remains below, grading upward into clayey or silty peat and/or gyttja layers.

b. The upper filling layer consists of a peat layer with thicknesses ranging from 0.5 up to 4 meters. Within the stratigraphy of the peat layer roughly two variants occur, a clayey peat on Sphagnum peat while a multi-layered peat sequence is present in the thickest total organic fillings and generally the peat becomes more eutrophic upwards. 


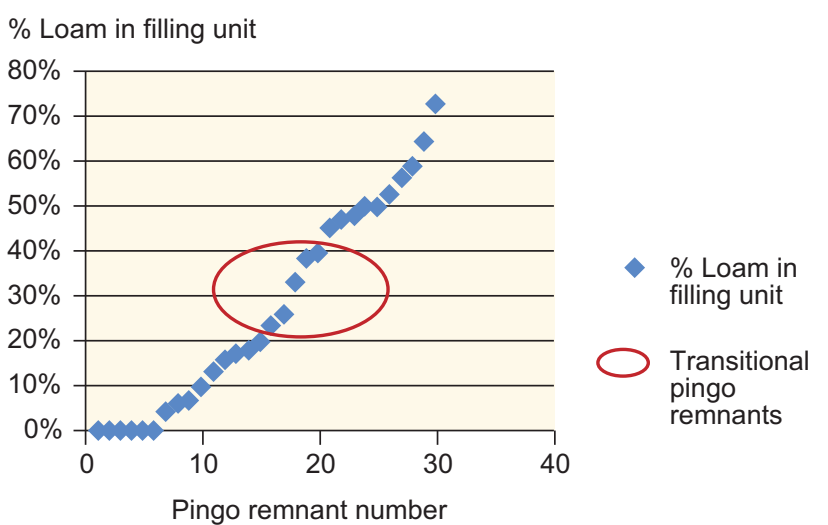

Fig. 4. Graph showing relation between pingo remnants, their proportion of loam in the filling unit, and division into two types. The plot of the percentages is transitional rather than abrupt, but given the clear geographical spreading of the two types the division into two types appears to be significant (Fig. 3).

Type $2(n=16)$ : The filling of the erosional form consists of two distinct layers: a) yellow-brown humic loam (incl. gyttja); and b) organic peat, in variable thicknesses (nrs 26, 47, 68, 96, $180,181,373,379,400,401,409,424,486$, and 576).

On average a humic loam layer is slightly larger in thickness than a peat layer: a humic loam layer is 1.8 meter and a peat layer

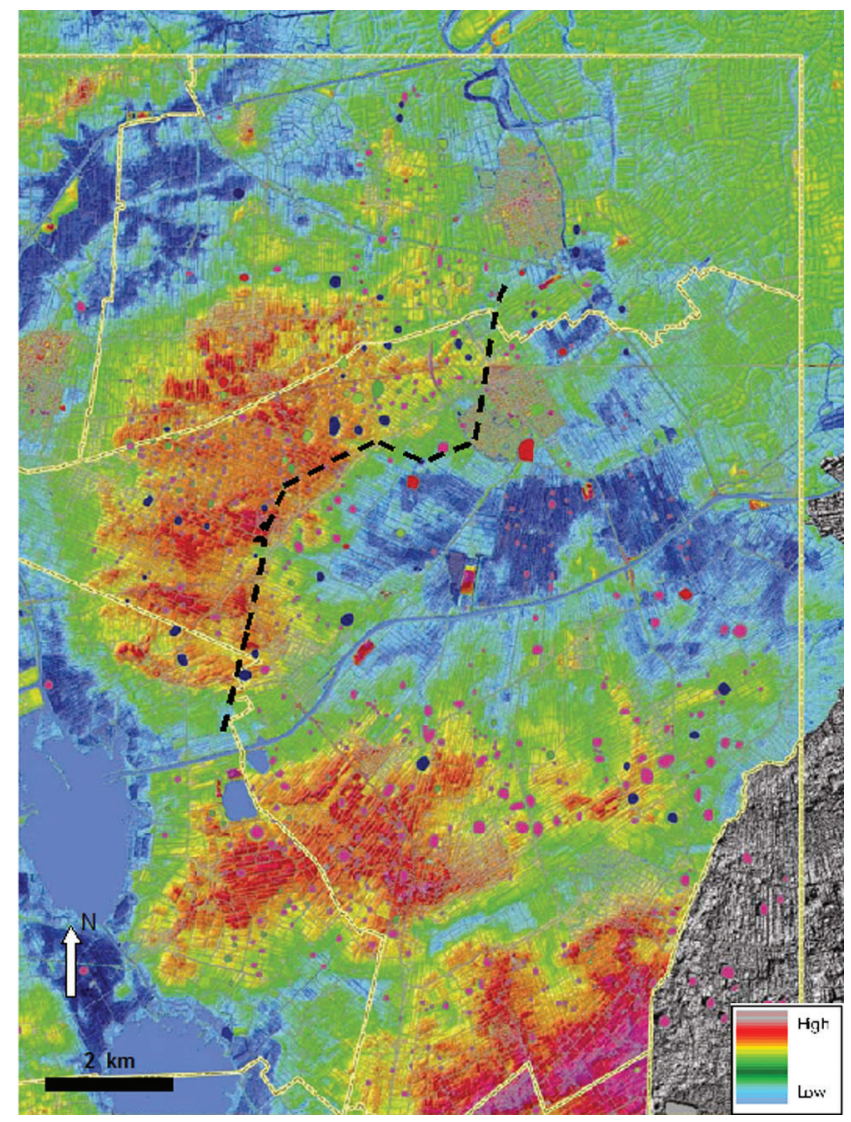

Fig. 5. Digital Elevation Model of study area. Line represents division between type 1 and type 2 pingo remnants. See Fig. 3 for site numbers (source map: Province of Friesland, 2006). is 1.3 meter (Table 3). In both layers nutrient-poor to -rich variations in the layer sequence are observed.

a. The basal filling layer has a thickness ranging from 0.4 up to $5.0 \mathrm{~m}$. The basal layer of a yellow-brown coloured loam is multi-layered with humus content variable in a vertical sense. Plant and root remains as well as layers of thin sand, clayey peat and gyttja occur in the basal filling layer (Fig. 6).

b. The upper filling layer has a thickness ranging from 0.7 to $2.3 \mathrm{~m}$. The upper filling layer consists mainly of peat, usually without any clay or silt admixture. Often thick layers of pure Sphagnum peat occur right above the humic loam layer. In the deeper pingo remnants a stratigraphy of multiple peat layers usually occurs. In the upper part of the peat sequence usually loamy or clayey peat units are found that are more more eutrophic in nature.

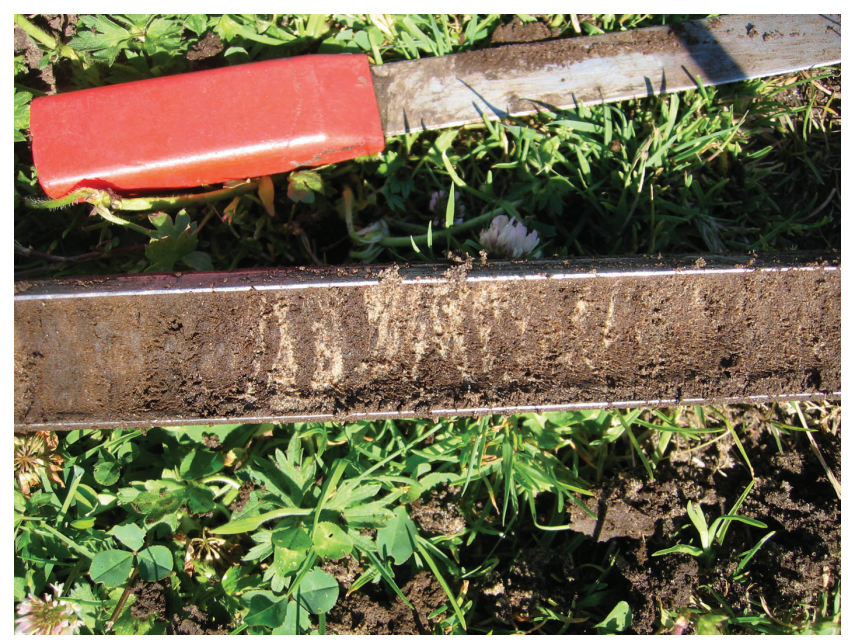

Fig. 6. Site 424, core B2, dark to red brown humus rich loam with layering of thin sand layers at 120-140 cm (type 2 pingo filling). Sedimentary structures reveal slumping processes.

\section{Cover layer}

The cover layer in all pingo remnants consists mostly of sand, which is in most cases anthropogenically influenced. In fewer cases also remnants of glacial till have been used to fill up the marshy depression. In a single case the cover layer is not present; the top of the undisturbed organic filling consists of a sandy humic loam with soil forming characteristics. The sand may be derived from windblown activity. When a clay layer is present a good conservation of the organic filling underneath the cover layer is provided. The clay layer in this region is originating from a regional marine incursion during Medieval times.

In addition of the general results of the description of sedimentary logs in Table 2, the nature of observed units two class I examples of site description, sites 603 (type 1) and 181 (type 2) are given. 


\section{Pingo remnant 603, Buitenpost, type 1}

Within the sequence of pingo remnant 603 Buitenpost five lithostratigraphic units are distinguished, resp. from below: a) substrate: a silt poor clay (min. thickness $2.0 \mathrm{~m}$ ), below a sandy loam; b) a thin layer of fine to very fine sands with dark coloured minerals $(0.1-0.5 \mathrm{~cm}) ; \mathrm{c})$ sandy loam with variable humus content and content of plant remains (thickness 0 to $1.0 \mathrm{~m}$ ); d) peat with at the base plant rests (Sphagnum peat, thickness 0.5 to $4.0 \mathrm{~m}$ ); e) cover layer with marine clay and silt layer on top of it; fine well sorted sand at the fringes (thickness 0.3-1.0 m; Fig. 7a).

\section{Substrate}

The substrate material of site 603 consists of brown-grey to grey clay poor in silt interpreted as Elsterian clay (Peelo Formation, Nieuwolda member). In the bottom part of a core in the substrate of site 603 , below $4.5 \mathrm{~m}$ below surface (very) fine sand content increases upwards. The sand is correlated as lying on top of the pottery clay. These sands are interpreted also as Elsterian (Peelo Formation). On top of the clay reddish grey to grey clayey to sandy loam with gravel content is present with a weathering surface grading upwards into a light grey to brown clayey gravelly sand. These deposits are interpreted as a Saalian till (Drenthe Formation) as well as the leaching product of the till.

\section{Thin sand layer}

A thin layer of fine to very fine sands with dark coloured minerals $(0.1-0.5 \mathrm{~m})$ is present below the pingo filling in most cores, lying on top of the Elsterian pot clay.

\section{Sandy loam}

The lower filling layer in site 603 consists of a brown to grey coloured loam with traces of roots as well as thin lamina of sand. This corresponds with observations in basal loam units from other type 1 pingo remnants (Fig. 8). The upper part of the loamy unit has an enhanced humus content. The maximum thickness of the loam unit in location 603 is $60 \mathrm{~cm}$. The lowest part of the sandy loam in core 603-06 was dated $11,600 \pm 180$ C14 years BP (Fig. 7a).

\section{Peat}

Peat moss (Sphagnum peat) has thicknesses of $0.5 \mathrm{~m}$ at the sides to $4.0 \mathrm{~m}$ in the centre of the pingo remnant. An alternation of grey brown clay and eutrophic (clayey) peat layers forms the transition to the upper filling layer with red brown peat that is fibrous in its basal part and has thicknesses ranging 1.5-3.0 m.
Cover layer

The cover layer is a marine clay and a silt layer on top of it while fine well sorted sand occurs at the fringes (thickness 0.3-1.0 m). The base of the marine clay is radiocarbon dated between $490 \pm 60 \mathrm{C} 14$ years BP and the peat sample is dated at $285 \pm 45 \mathrm{C} 14$ years BP (Fig. 7a). The dates suggest that the clay was deposited after the Medieval period, which coincides with historical sources indicating marine incursions from the North Sea.

\section{Pingo remnant 181, Jistrum, type 2}

Within the stratigraphic sequence of pingo remnant 181 Jistrum five main lithostratigraphic units are distinguished, respectively: a) substrate: a sequence of heavy clay, followed by fine sands, a sandy gravelly loam, and on top (very) fine, well sorted sands; b) a thin layer of fine to very fine sands with dark coloured minerals (0.1-0.5 m); c) loam with variable humus content and content of plant remains (thickness $0.8-5.0 \mathrm{~m}$ ); d) peat with recognisable plant rests (Sphagnum peat) (thickness 0.7-2.6 m); e) cover layer: fine well sorted sand at the fringes (thickness 0.3-1.0 m; Fig. 7b).

\section{Substrate}

The substrate material of site 181 consists of a dark grey heavy clay, interpreted as Elsterian potclay (Peelo Formation, Nieuwolda member), a very fine to moderately fine grey sand (105-210 $\mu \mathrm{m})$ interpreted as Elsterian fluvioglacial deposits (Peelo Formation), and a light grey strong sandy, weakly gravelly loam, interpreted as Saalian till (Drenthe Formation). The till is only observed on the undisturbed sides of the erosional form and also occurs as the weathered product of till higher up in the till layer: moderately fine sand (150-210 $\mu \mathrm{m})$ with gravel. The undisturbed substrate shows on top of the till layer a very fine to moderately fine, well sorted grey to brown sand with enhanced humus concentrations. The upper layer of the substrate is interpreted as Weichselian eolian (cover) sands with soil development. The soil is interpreted as Holocene; soil formation has taken place after pingo formation and after the subsequent filling process.

\section{Fine sand layer}

On top of the eroded substrate, in the deepest part, a thin layer of 0.1 to $0.2 \mathrm{~m}$ grey to light grey very fine sand (105-150 $\mu \mathrm{m})$ with dark coloured minerals and mica is present. This layer increases in thickness to $0.3-0.5 \mathrm{~m}$ of very fine sand (63-105 $\mu \mathrm{m})$ to the sides of the erosional form. 


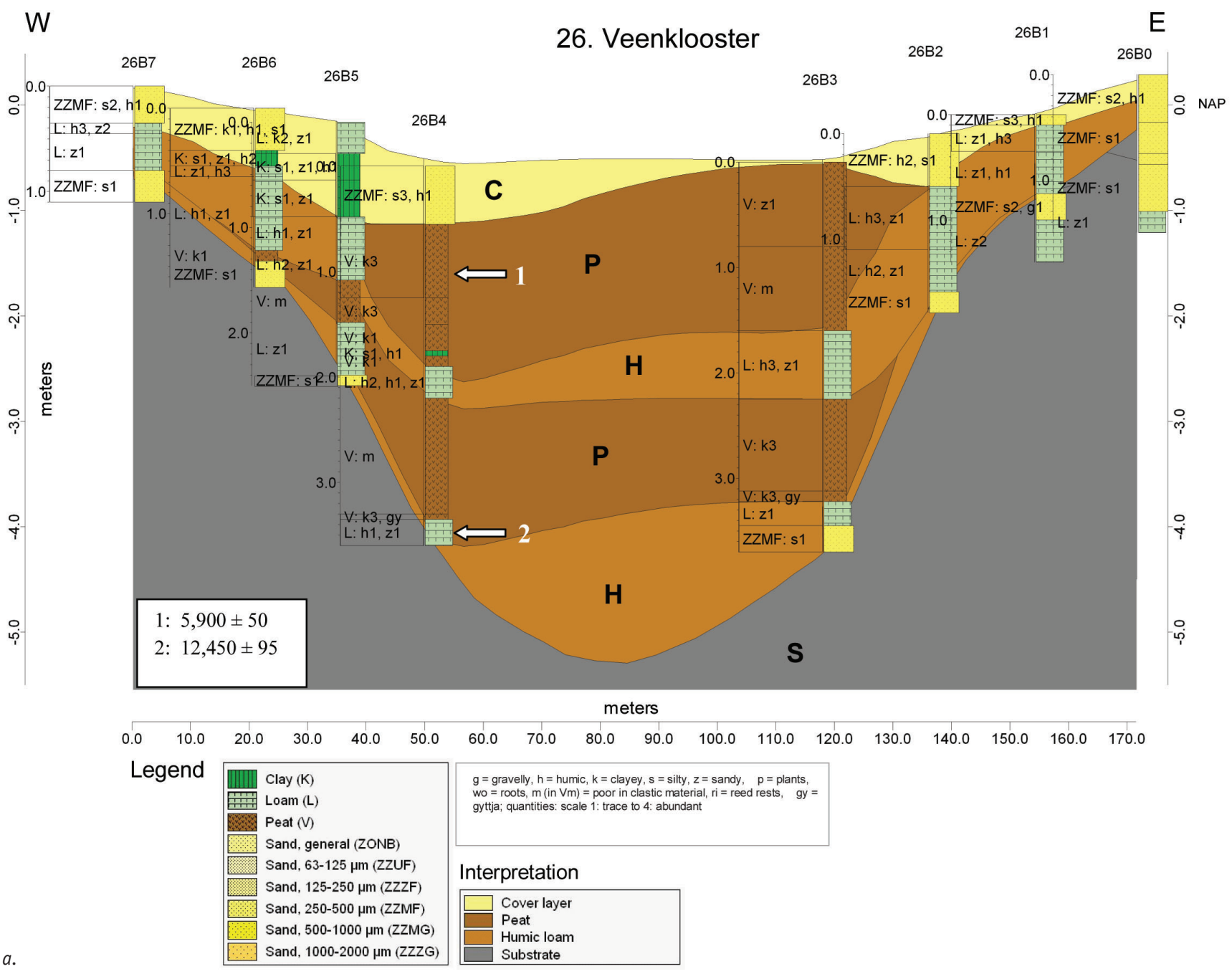

$\mathrm{N}$

603. Buitenpost

$S$

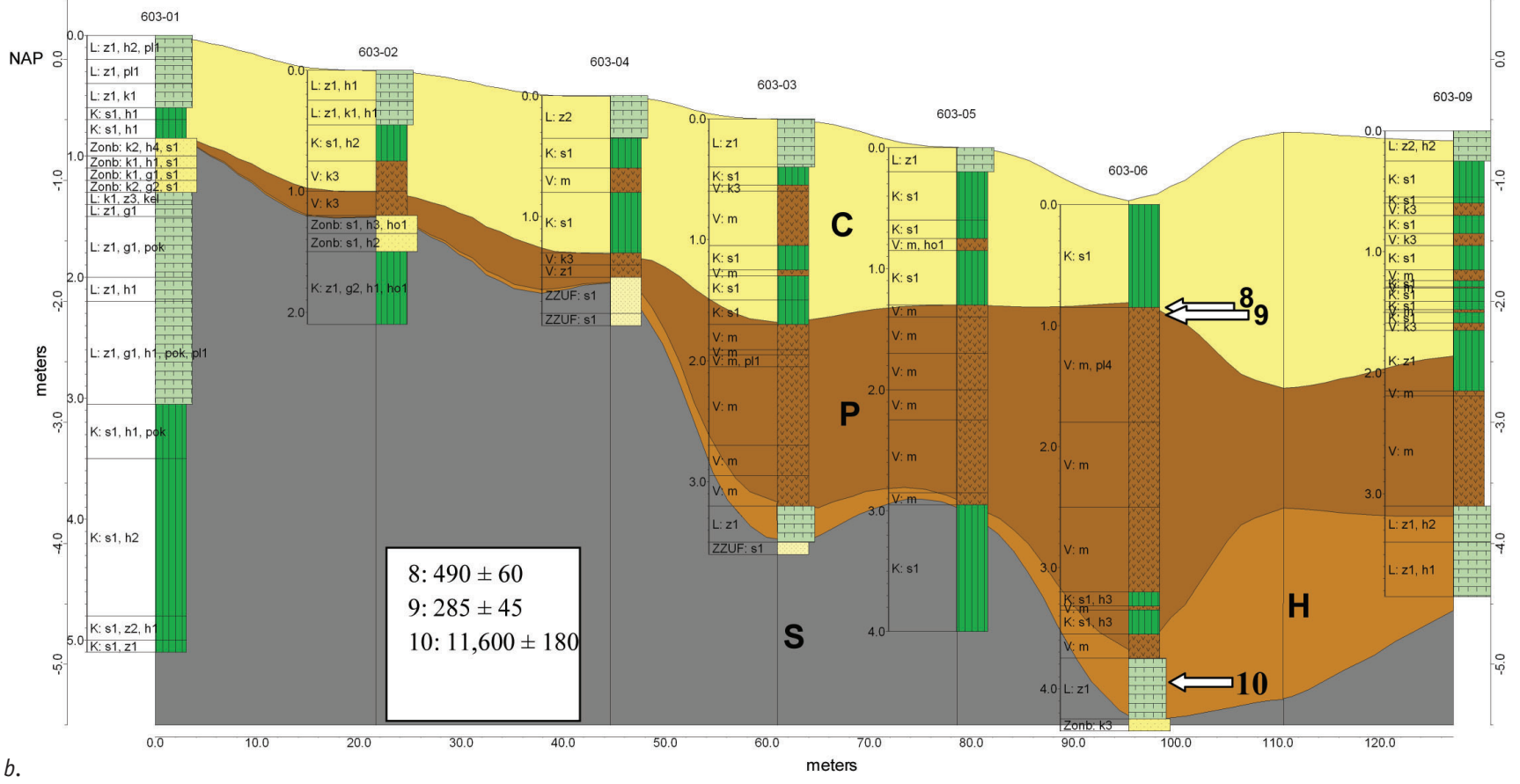




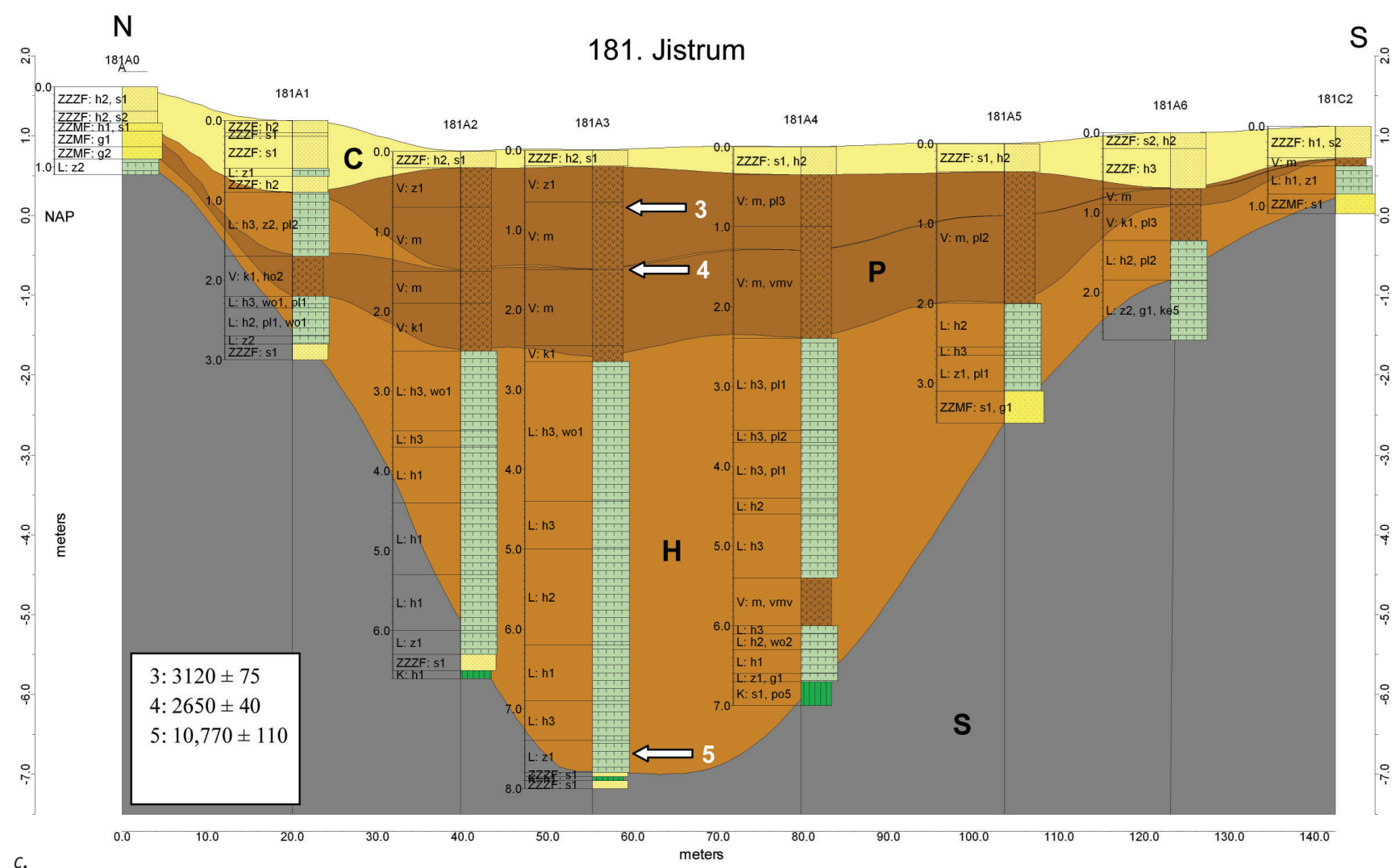

S

342. Twijzel

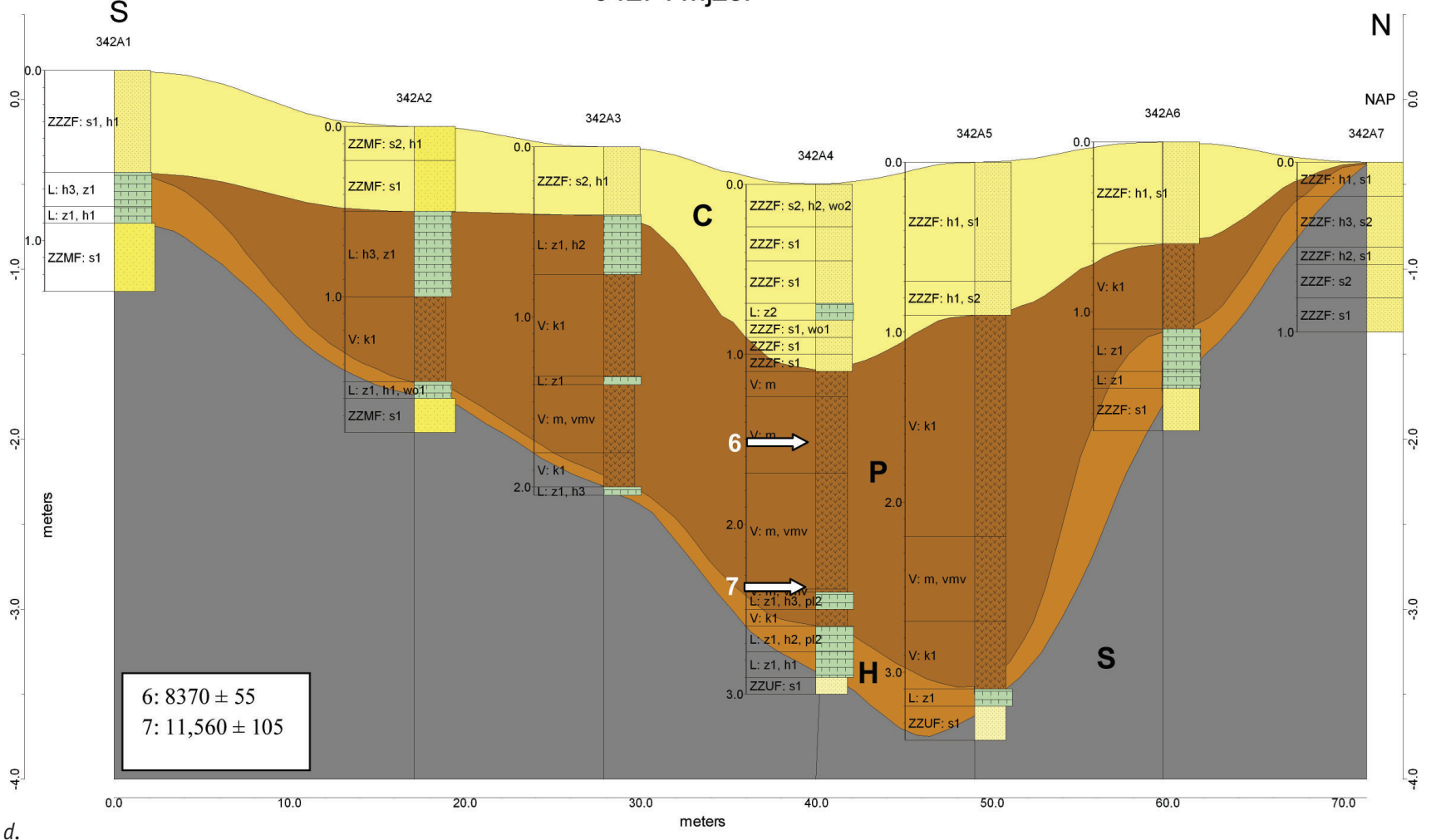

Fig. 7. Cross sections of pingo remnants. a. Site 26 (Veenklooster); b. Site 603 (Buitenpost); c. Site 181 (Jistrum); d. Site 342 (Twijzel). Uncalibrated radiocarbon dates in years $B P$ are indicated in the cross-sections. Consult also Table 4. Interpreted units: $S=$ Substrate, $H=$ Humic loam, $P=P e a t, C=C o v e r$ layer. 


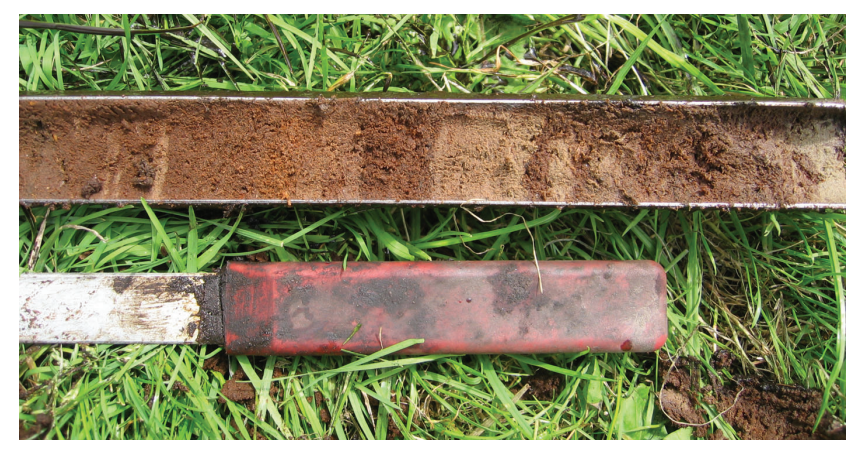

Fig. 8. Site 99, core A1, 230-240 cm: thin sand layers in red brown peat, rich in silt, at base of organic filling (type 1 pingo filling).

\section{Loam}

The lower filling unit of the erosional form consists of light grey to grey weak sandy loam layers at the base grading upwards to dark brown to yellow grey loam layers with variable content of humus and plant remains. Also intercalations of dark brown peat moss layers are prominent in the lower filling unit. The top layer of the lower filling unit consists usually of a dark brown loam with high humus content, containing plant roots. In a single core the upper part of the lower filling unit consists of brown medium sized sand (150-210 $\mu \mathrm{m})$, with a content of medium humus and minor plant remains. The sandy layer is topped by a relatively thin clayey peat layer with a minor content of plant remains. The maximum thickness of the loam unit in site 181 is $5.0 \mathrm{~m}$ and is directly overlain by the peat unit. One of the basal humus-rich layers in the loam unit is dated $10,770 \pm 110$ years BP (Fig. $7 b$ ).

\section{Peat}

The upper filling unit of the erosional form consists of an orange to red brown ombrotrophic peat layer (Sphagnum peat) that is fibrous in its basal part. The upper part of the peat sequence shows black colours and physical properties indicating certain degrees of mouldering. The mineral content increases upward with a higher content of sand- and clay particles in the peat, while the peat turns more eutrophic. The maximum thickness of the peat layer is 2.6 meters. Two sandy peat samples in the upper peat unit are respectively dated $2650 \pm 40 \mathrm{BP}$ and $3120 \pm 75$ BP (Fig. 7b). The sandy nature of the peat may reflect the input of windblown sand during the Bronze Age - Iron Age archaeological period.

\section{Cover layer}

The cover layer is positioned on top of the peat sequence, as well as on top of the non-eroded substrate, and consists of a silt containing dark to grey brown sand with moderate humus content in the upper horizons. On top of the non-eroded substrate differences in humus and colour content in the cover layer indicate that podzolic soil profiles, while on top of the peat sequence only changes in humus content occur and clear soil profiles are lacking.

\section{Chronology of pingo fill stratigraphy}

The radiocarbon dates presented in this study, although uncorrected and uncalibrated, show that within the measured dataset the entire sedimentary filling sequence is present dating most likely from the Late Glacial through the Holocene. In addition to sites 603 and 181, also sites 26 (Veenklooster) and 342 (Twijzel) have been dated (Table 4).

Site 26 is a type 2 pingo remnant, as site 181, but contains in fact a 'double' type 2 stratigraphy (Fig. 7c). A basal light brown to brown grey loam with low humus content underlies a black clayey peat to dark brown loam with strong humus content, interpreted as an organic gyttja. The gyttja was dated $12,450 \pm 95$ C14 years BP implying a Late-Glacial age for the first pingo infilling (Table 4). In the deepest part the gyttja is overlain by more than a meter of ombrotrophic red brown moss peat, grading laterally into clayey peat. The moss peat is

Table 4. Results of conventional radiocarbon dating as performed by the Groningen University (RUG). No reservoir corrections have been applied and the dates are presented as uncalibrated years $B P$.

\begin{tabular}{|c|c|c|c|c|c|c|c|}
\hline Location & X-coordinate & Y-coordinate & $\begin{array}{l}\text { Pingo remnant } \\
\text { site number }\end{array}$ & $\begin{array}{l}\text { Sample } \\
\text { number }\end{array}$ & $\begin{array}{l}\text { Depth (-cm } \\
\text { below surface) }\end{array}$ & $\begin{array}{l}\text { Radiocarbon date } \\
\text { BP, uncorrected }\end{array}$ & Sediment \\
\hline Veenklooster & 202.861 & 587.124 & 26 & GrN-31166 & $112-115$ & $5900 \pm 50$ & Moss peat? \\
\hline Veenklooster & 202.861 & 587.124 & 26 & GrN-31167 & $275-278$ & $12,450 \pm 95$ & Brown organic gyttja \\
\hline Jistrum & 200.466 & 581.182 & 181 & GrN-31168 & $85-88$ & $3120 \pm 75$ & Sandy peat \\
\hline Jistrum & 200.466 & 581.182 & 181 & GrN-31203 & $145-149$ & $2650 \pm 40$ & humified sandy peat \\
\hline Jistrum & 200.466 & 581.182 & 181 & GrN-31169 & $722-725$ & $10,770 \pm 110$ & Peaty gyttja \\
\hline Twijzel & 202.630 & 582.489 & 342 & GrN-31170 & $152-155$ & $8370 \pm 55$ & Red brown moss peat \\
\hline Twijzel & 202.630 & 582.489 & 342 & GrN-31171 & $235-239$ & $11,560 \pm 105$ & Moss peat \\
\hline Buitenpost & 207.436 & 586.031 & 603 & GrN-31003 & $109-111$ & $490 \pm 60$ & Clay \\
\hline Buitenpost & 207.436 & 586.031 & 603 & GrN-31202 & $111-115$ & $285 \pm 45$ & Peat \\
\hline Buitenpost & 207.436 & 586.031 & 603 & GrN-31004 & $420-422$ & $11,600 \pm 180$ & Grey gyttja \\
\hline
\end{tabular}


overlain by a strong humic loam, followed by a brown black eutrophic peat, variable in clay content. The upper half of this peat layer is dated $5900 \pm 50$ C14 years BP, indicating a correlation with the Neolithic age.

Site 342 is a type 1 pingo remnant, as site 603, and has a layered sequence in the lower half and a homogenous sequence in the upper part (Fig. 7d). The basal unit is a thin loam layer with low humus content increasing upwards. The loam layer is followed by a clayey peat and compressed peat moss layers. One of these peat moss layers is dated 11,560 105 C14 years BP, implying a Late Glacial age for the initiation of the pingo remnant filling. Upwards the organic filling grades into a red to orange brown moss peat. Less than 1 meter on top of the basal date the moss peat is dated to $8370 \pm 55$ C14 years BP (Fig. 7d), implying a correlation with the Neolithic age or the Mesolithic-Neolitic transition period (Table 4). The orange to red brown peat moss is grading vertically and laterally into clayey peat units (Fig. 7d).

\section{Discussion}

Results of the present field study show that two-third of the selected circular landforms in the study area represents pingo remnants. To extrapolate that factor to the total of 250 circular landforms present in this study area means that about 175 out of 250 of these landforms may represent true pingo remnants. Most likely this regional estimated number of pingo remnants is lower since the 45 selected sites for this study did not have a random procedure for selecting study sites, but instead an attempt was made to select as many 'true' pingo remnants.

During maximal ice occupation in the northern Netherlands in the Saalian, during a northeastern ice flow event, subglacial till has been deposited in elongated NE-SW ridges (Figs 2 and 5). In the lower part of the terrain, the thickness of glacial till is less or absent due to Saalian and Weichselian erosion by melt water channels and tributaries of periglacial snowmelt water (Bosch, 1990).

In the Weichselian during the process of pingo formation, the subsurface was deformed by the growing ice lense in most cases down to the Elsterian base. This means that the Saalian till, as well as the Elsterian sand and potclay have been pushed away by the growing ice lense. The erosional products will have to be deposited elsewhere to create accommodation space for the growing ice lense. In this study so far no gravel has been found in the lower filling units or at the top of the substrate materials. The thin sand layer present at the base of the organic filling represents another argument for the reworking hypothesis. The composition of the sand reflects a provenance from the Elsterian Peelo formation, with very fine sands (63-150 $\mu \mathrm{m})$ with glauconite and mica as dominant lithological characteristics (Zagwijn, 1973; Doppert et al., 1975). This is in agreement with the lithological description of dark minerals and mica in a very fine grained sandy matrix in this study. The association of the thin layer of sand is its superposition on the erosional surface created by the pingo formation process and its position of underlying the base of the pingo filling unit. The provenance of the sand and its stratigraphic position may imply a deposition of very fine grained sands at the early stages of pingo collapse, i.e. before complete melting of the ice lense, and prior to the subsequent filling of the erosional form. Inferring from the shape, thickness and association of the thin sand layer it must have been deposited by a yet unknown process in a small wedge between the ice and the erosional form. Judging from the radiocarbon dates in the overlying organic filling this 'deposition' of the thin sand layer must have occurred before or in the Late-Glacial (Table 4).

One of the most interesting results is the spatial criterion with respect to the two distinguished types of organic filling potentially caused by substrate differences. On the higher till plateaus pingo remnants generally show a two-layered filling stratigraphy of humus-rich loam and peat, while on the lower terrain most of the pingo remnants are filled in with a peat succession, and with a considerable minor extent of (humusrich) loam. The distinguishing factor between these two types is the loam thickness (Figs 3,5). In addition it can be deduced from the measured variables that type 2 pingo remnants (on the till plateaus) generally have a greater depth, are more ellipsoid in shape, and have a steeper slope angle than type 1 pingo remnants on the lower terrain.

Comparing radiocarbon results of the four discussed pingo remnants (sites 26, 181, 342, and 603) it appears that the oldest dates, although maximum ages, point to a Late Glacial origin of the basal pingo fill unit (Table 4). This age corresponds with other dated pingo remnants in the southern Netherlands (Late Glacial Older Dryas: Kasse \& Bohncke, 1992). In the northern Netherlands this is supported in general by pollen data by De Gans (1981) and De Gans \& Cleveringa, (1981) and also by Paris et al. (1979) who dated the melting of the Stokersdobbe pingo in Friesland between 13,000 and 18,000 BP. The thin sand layers within the basal filling unit of humic loam (e.g site 603) may reflect the Younger Dryas period (Hoek \& Bohnncke, 2002; Hoek, 2005), which is conform to a Late Glacial age of start of infilling of the pingo remnants in the study area. This Younger Dryas sand is usually located on top of an older organic layer. Pingo remnant 181 (Jistrum) shows a relatively thick loam unit. The radiocarbon dates imply that through much of the Holocene the pingo remnant remained a type of marsh environment rather than a peat bog, like most likely was the case in type 1 pingo remnants 342 and 603. This has implications for the interpretation of the environment in pingo remnants through the Holocene, implying that type 2 pingo remnants have a different landscape evolution than type 1 pingo remnants. It can be inferred from the results of this study that the higher NE-SW trending till ridges of the till plateau showed a Holocene period of a marsh environment followed by a peat bog environment in the pingo remnant (e.g. site 181). This 
environment contrasts with the peat bogs that have developed much earlier and continuously in the Holocene in the lower regions (e.g. site 342). This difference in landscape evolution between the till ridges and the lower surface in the region may have an impact on the habitation patterns of the earliest cultures that arrived into this landscape in the Holocene. The difference of loam thicknesses between the type 1 and type 2 pingo remnants possibly reflects differences in local (palaeo) ground water levels between the two specific landscape sites. Typical pattern is the presence of ombrotrophic Sphagnum peat at the base of both peat fillings (type 1 and 2) generally grading upwards to more meso- and eutrophic peat types, like e.g. sedge peat.

The thirty pingo remnants described in this dataset show in their lower filling unit a distinct layering of humic loam and only a minor presence of gyttja. Other pingo remnants, e.g in the province of Drenthe (25-50 km southeast of the present study area), often show thick sequences with gyttja (organic mud) in the basal filling (De Gans, 1982, 1988; Hoek, 2005). Is this difference in the nature of filling due to regional variation in e.g. substrate or due to descriptive standard discrepancies? And where do all the loam particles in the humic loam units in the Friesland pingo's originate from? Substrate varies with Saalian till near the surface most dominantly in the Drenthe area, with Elsterian clay and sand near the surface more dominant in the Friesland area. Some palynological studies have suggested that in the early stages of the pingo filling process in the Late Weichselian eolian processes could have transported sand and loam in a barren landscape with hardly any vegetation to stabilise the surface (Bottema et al, 1990). Because of the dominance of outcropping Elsterian clay and Saalian (clayey) till in the Friesland area, loam particles could potentially originate by wind erosion from these surfaces.

In most pingo remnants in this study the basal filling layer has been relatively devoid of organic material, usually with a layering of variable humic content present, sometimes increasing upwards in organic content. Right on top of the loam unit in most pingo remnants moss peat (sphagnum) was cored. These ombrotrophic conditions of the environment most likely point to conditions of the substrate, (palaeo) groundwater conditions as well as the (lack of) vegetation at the surface at that time. The Elsterian pot clay, sands and Saalian till cannot deliver organic material to the nature of the filling of the pingo remnants.

\section{Conclusions}

1. This study describes the presence of several hundreds of circular depressions in the province of Friesland, most of them presumable pingo-remnants.

2. The fills in these pingo remnants differ, related to the subsoil in which they developed. Pingo remnants are filled with a relatively thick peat succession underlain by a minor layer of humic loam (type 1) or consist of a considerable part of loam which contains a high percentage of humus or gyttja and peat, followed by a peat layer (type 2). Type 2 pingo remnants on the till plateaus generally have a greater depth, are more ellipsoid in shape, and have a steeper slope angle than type 1 pingo remnants in the lower terrain.

3. Radiocarbon dating of the fill unit is implying a minimum age in the Late Glacial period for the initiation of the filling process of the humic loam. But in those cases where the eolian sand of the Boxtel Formaton is deformed by the pingo shape, the time of pingo formation is younger than the eolian deposition period. The dating implies that pingo remnants on the till plateaus through much of the early Holocene exhibited a marshy landscape rather than a peat bog terrain.

4. All thirty identified pingo remnants have a (thin) fine sand layer at the interface of substrate and organic filling. The sand is interpreted to be of the Elsterian Peelo Formation and is most likely reworked during the pingo formation process during or before the Late-Glacial of the Weichselian. It is almost as if the organic filling is 'sealed' by the fine sand layer. We infer that this sand layer plays a role in the thawing/freezing process as it facilitates the transport of (melt) water more easily than the hard permeable clay-rich substrates of pottery clay and subglacial till.

5. A visible rampart surrounding the pingo remnant is not a necessary diagnostic condition in this region.

The type of organic filling of the pingo remnant reflects the nature of substrate the pingo has originally developed in. Pingo fills which developed on the higher till ridges show a two-layered stratigraphy of humic loam and peat while pingo fills in the lower terrains show a single layered stratigraphy of peat. It has been demonstrated that substrate lithology influences pingo shape and depth. It has been demonstrated that there is a relation between the depth and shape of organic filling, the angle of inclination of the pingo remnant and the lithological character of the organic filling.

Research on a large dataset of pingo remnants in a specific part of a Pleistocene landscape offers the opportunity to test specific data variables on a large spatial scale. The relation between pingo fill units, substrate, and pingo remnant size and shape parameters can be explored. In this study it has been demonstrated that 30 out of 45 investigated sites represent true pingo remnants. Radiocarbon data in combination with stratigraphic relations prove that infilling in a number of pingo remnants has started since the Late-Glacial. Two types of organic filling can be distinguished which can be tied to differences in substrate in a formerly glaciated landscape. Future palaeobotanic studies in pingo remnants in conjunction with palaeo-groundwater reconstructions and AMS dating, incorporating the results of this study, may yield a better reconstruction of different patterns of Holocene landscape evolution in relation to the emergence of Mesolithic and Neolithic cultures in this region. 


\section{Acknowledgements}

This research would have been impossible without the effort of a large team that helped to obtain the cores from 45 sites; thank you Ancko Boonstra, Elmer Cladder, Michiel Dekker, Anke van der Geest, and Theo van der Meulen. Jacco Wanders assisted in the preparation of cross-sections and maps. Henk Woldring of the Groningen Institute for Archaeology is thanked for supplying radiocarbon data. Reviews by Wim de Gans and Wim Hoek have considerably improved the quality of the paper. Harke Jan van der Meulen kindly corrected the English. AV and WT acknowledge the support of Syncera during their work on the Pingo Project Fryslân, (PPF).

\section{References}

Bakker, R., 2003. The emergence of agriculture on the Drenthe Plateau - a palaeobotanical study supported by high resolution ${ }^{14} \mathrm{C}$ dating. Archäologische Berichte 16. Bonn.

Bijlsma, S. \& De Lange, G.W., 1983. Geology, palynology and age of a pingo remnant near Daarle, Province of 0verijssel, the Netherlands. In: Terwindt, J.H.J. \& Van Steijn, H. (eds): Developments in physical geography; a tribute to J.I.S. Zonneveld. Geologie en Mijnbouw, 62: 563-568.

Bos, J.A.A. \& Janssen, C.R., 1996. Local impact of Palaeolithic man on the environment during the end of the Last Glacial in the Netherlands. Journal of Archaeological Science 23: 731-739.

Bosch, J.H.A., 1990. Assen West (12W) en Assen 0ost (120). Toelichtingen bij de Geologische kaart van Nederland 1: 50,000. Rijks Geologische Dienst (Haarlem): 1-168 pp.

Bosch, J.H.A., 2000. Standaard Boor Beschrijvingsmethode (en NEN5104), Versie 5.1. TN0-rapport NITG 00-141-A: $106 \mathrm{pp.}$

Bottema, S., Groenendijk, H.A. \& Mook-Kamps, E., 1990. Archeologisch en palynologisch onderzoek van een pingo te Wildervank (Gr.). Paleo-aktueel 2: 15-18.

Davies, S.M., Hoek, W.Z., Bohncke, S.J.P., Lowe, J.J., Pyne O'Donnell, S. \& Turney, C.S.M., 2005. Detection of Lateglacial distal tephra layers in the Netherlands. Boreas, 34: 123-135.

De Gans, W., 1982. Location, age and origin of pingo remnants in the Drentsche Aa Valley area (the Netherlands). Geologie en Mijnbouw 61: 147-158.

De Gans, W., 1988. Pingo remnants and their identification. In: Clark, M.J. (ed.) Advances in periglacial geomorphology. John Wiley \& Sons (Chichester, United Kingdom): 299-322.

De Gans, W., 2000. Het Uddelermeer, een geologische schatkamer. Natuur \& Techniek, december 2000, 54-58.

De Groot, Th.A.M., Cleveringa, P. \& Klijnstra, B., 1989. Seizoens-ijsheuvels, een bijzonder geologisch verschijnsel. Grondboor en Hamer, jrg. 43, 1: 1-10.

De Groot, Th.A.M., Cleveringa, P. \& Klijnstra, B., 1987. Frost-mound remnants and the evolution of a Late Dryas environment (northern Netherlands). Geologie en Mijnbouw 66: 239-250.

Doppert, J.W.C., Ruegg, G.H.J., Van Staalduinen, C.J., Zagwijn, W.H. \& Zandstra, J.G., 1975. Formaties van het Kwartair en Boven-Tertiair in Nederland. In: Zagwijn, W.H. \& Van Staalduinen, C.J. (eds): Toelichting bij geologische overzichtskaarten van Nederland. Rijks Geologische Dienst, Haarlem: 11-56.
Hoek, W.Z. \& Bohncke, S.J.P., 2002. Climatic and environmental events over the Last Termination as recorded in The Netherlands: a review. Netherlands Journal of Geosciences 81: 123-137.

Hoek, W.Z., 2005. Tefrochronologie. Grondboor \& Hamer, 3: 72-76.

Kasse, K. \& Bohncke, S.J.P., 1992. Weichselien Upper Pleniglacial Aeolian and Ice-cored Morphology in the southern Netherlands (Noord-Brabant, Groote Peel). Permafrost \& Periglacial Processes, 3: 327-342.

Kluiving, S.J. \& Verbers A., 2007. Evaluatie van het onderzoek naar vijfenveertig locaties van vermeende pingoruïnes in het oosten van de Provincie Friesland: Pingo Project Fryslân (PPF) en Catalogus Pingo Project Fryslân 2006-2007. ISSN 1872-2350, GE0-LOGICAL reeks 02 (incl. cd-rom) (Delft): 28 pp.

Maarleveld, G.C. \& Van den Toorn, J.C., 1955. Pseudo-solle in Noord-Nederland. Tijdschrift Koninklijk Nederlands Aardrijkskundig Genootschap, 72: 344-360.

Mackay, J.R., 1998. Pingo growth and collapse, Tuktoyatuk peninsula area, Western Arctic Coast, Canada: a long-term field study. Géographie Physique et Quaternaire, 52: 271-323.

Nossin, J.J., 1961. De reliëfontwikkeling in Zuidoostelijk Friesland. Boven Boorne gebied. Wâldrige 9, 178: 48-70.

Paris F.G., Cleveringa, P. \& De Gans, W., 1979. The Stokersdobbe; geology and palynology of a deep pingo remnant in Friesland (the Netherlands). Geologie en Mijnbouw, 58: 33-38.

Van Geel, B., Bohncke, S.J.P. \& Dee, H., 1981. A palaeoecological study of an upper late glacial Holocene sequence from the 'De Borchert', the Netherlands. Review of Paleobotany and Palynology, 31, 367-448.

Van der Meulen, S., 1988. The spatial facies of a group of pingo remnants on the southeast Frisian till plateau (the Netherlands). Geologie en Mijnbouw 67: 61-74.

Zagwijn, W.H., 1973. Pollenanalytic studies of Holsteinian and Saalian Beds in the northern Netherlands. Mededelingen Rijks Geologische Dienst, N.S., 24: 139-156. 
